\title{
Ergste sterfgeval
}

Met een brok in mijn keel kijk ik naar haar verstilde lichaam. Met een laatste zucht laat ze het leven los. De rust die in haar slaapkamer hangt, en de stilte die zich meester heeft gemaakt van haar lichaam lijkt onwerkelijk. Mijn collega maakt zwijgend haar hand los uit de hare. De arts die aan het bed staat zucht. Ik kijk om me heen. De thee, die ik haar een uur geleden bracht, staat nog naast haar luie stoel. De postoel, waar ze al gillend op werd gezet, omdat collega's dachten dat ze weer eens obstipatie had, staat in een hoek geschoven. Mijn eigen stem blijft door mijn hoofd galmen: 'Ze heeft geen obstipatie, ze kwam net van het toilet toen ik haar de thee bracht. Ze heeft een hartaanval! Bel de arts!'

Op de tafel liggen meerdere opengebroken ampullen Morfine en Dormicum. De spuiten liggen ernaast. De arts heeft haar alles gegeven wat in haar macht lag, deed er alles aan om haar gillen en krijsen door pijn en angst af te laten nemen. Een blik van de arts, bij binnenkomst, was voldoende, 'Ze gaat het niet redden, ze gaat overlijden, leg haar op bed.' Het was makkelijker gezegd dan gedaan. Als ze lag, werd de pijn erger. Steeds kwam ze, al gillend, op de bedrand zitten. Uiteindelijk zijn mijn collega en ik, ieder aan een kant van haar gaan zitten. Als een klein kind streken we haar door haar haren. Wanneer ze krijsend voorover boog om de pijn tegen te gaan, lieten we haar bezwete hoofd, om beurten, rusten bij een van ons op schoot. We susten haar, we troostten haar. ' $\mathrm{Ga}$ maar, het is goed zo. Je hebt genoeg gevochten. We laten je nu niet alleen...'

\section{'Steeds kwam ze, al gillend, op de bedrand zitten'}

Ik kijk naar mijn collega, ze ziet bleek. Tranen prikken achter mijn ogen. 'Ik moet even naar de gang', stamel ik. De arts knikt. Mijn collega loopt, als vanzelfsprekend, mee. Op de gang zwijgen we, al had ik liever willen schreeuwen. Als iemand zo moet lijden en letterlijk doodsangsten uitstaat, dan breekt je hart in duizend stukjes. De dood hoort erbij, maar ik zie mensen toch liever sterven als ze rustig in bed liggen en na een ziekbed hun laatste adem uitblazen. Gelukkig vind ik steun bij mijn team, maar in dit geval krijg ik ook veel steun van de geestelijk verzorger. Ik heb wel een paar uur met haar gepraat, zo'n impact had het. Vooral omdat ik me zo machteloos voelde. Toch weet ik dat mijn aanwezigheid van waarde was voor mevrouw. Ik hoop dat mijn troost en nabijheid haar een klein beetje verlichting gaven in haar pijnlijke doodsstrijd. Want geen mens mag eenzaam en alleen sterven.

Wendeline Roest (30) werkt als evv'er op een kleinschalige woongroep met ouderen met dementie. 